Cavallini, D. \& Stirpe, F. (1957). Ital. J. Biochem. 6, 1. Dodgson, K. S., Powell, G. M., Rose, F. A. \& Tudball, N. (1961). Biochem. J. 79, 209.

Dodgson, K. S., Powell, G. M. \& Tudball, N. (1960). Biochem. biophys. Res. Commun. 2, 130.

Dodgson, K. S. \& Tudball, N. (1960). Biochem. J. 74, 154.

Doy, C. H. (1960). Nature, Lond., 529, 4724.
Knox, W. E. \& Pitt, B. M. (1957). J. biol. Chem. 225, 675. Lin, E. C. C., Pitt, B. M., Civen, M. \& Knox, W. E. (1958). J. biol. Chem. 233, 668.

Powell, G. M., Rose, F. A. \& Dodgson, K. S. (1963). Biochem. J. 87, 545.

Ringertz, N. R. \& Reichard, P. (1960). Acta chem. scand. 14, 303.

Schwarz, K. (1961). Arch. Biochem. Biophys. 92, 168.

Biochem. J. (1963) 87. 545

\title{
Studies on L-Tyrosine $O$-Sulphate
}

\section{IDENTIFICATION OF $p$-HYDROXYPHENYLPYRUVIC ACID [ ${ }^{36}$ S]SULPHATE AS A METABOLITE OF L-TYROSINE $O\left[{ }^{35}\right.$ S]-SULPHATE IN THE RAT}

\author{
By GILliaN M. POWELL, F. A. ROSE AND K. S. DODGSON \\ Department of Biochemistry, University College, St Andrew's Place, Cardiff
}

(Received 11 December 1962)

Dodgson, Powell, Rose \& Tudball (1961) have shown that $p$-hydroxyphenylacetic acid $\left[{ }^{35} \mathrm{~S}\right]$ sulphate and an unknown $\left[{ }^{35} \mathrm{~S}\right]$ sulphate ester are present in the urine of rats that have been injected with L-tyrosine $O\left[{ }^{35} \mathrm{~S}\right]$-sulphate. The identity of the unknown ester has now been established as $p$-hydroxyphenylpyruvic acid $\left[{ }^{35} \mathrm{~S}\right]$ sulphate. A preliminary account of this work has been given (Powell, Rose \& Dodgson, 1962).

\section{MATERIALS AND METHODS}

Sulphate esters. Potassium L-tyrosine $O\left[{ }^{35} \mathrm{~S}\right]$-sulphate was prepared as described by Dodgson et al. (1961). Other sulphate esters were obtained as described by Rose \& Powell (1963).

Paper chromatography. Descending chromatograms were run overnight on Whatman no. 1 paper with butan-1-olacetic acid-water (50:12:25, by vol.). Sufficient material was applied to the paper to give approx. 500 counts $/ \mathrm{min}$. (measured on the paper with a Panax monitor). Radioactive areas were located with the $\mathrm{C} 100$ Actigraph automatic strip scanner (Nuclear-Chicago Corp., Ill., U.S.A.) or by radioautography.

Paper electrophoresis. The conditions described by Rose \& Powell (1963) were used. Separation of inorganic sulphate and the sulphate esters of $p$-hydroxyphenylpyruvic acid, $p$-hydroxyphenylacetic acid, $p$-hydroxybenzaldehyde and L-tyrosine could be achieved, the rate of movement towards the anode decreasing in that order.

Experimental animals. Female M.R.C. hooded rats (aged 2-4 months) were used throughout. These animals were injected intraperitoneally under light ether anaesthesia and were subsequently placed in metabolism cages designed to permit separate collection of urine and faeces. The first voided urines were collected and either used immediately or stored at $-20^{\circ}$ until required.

\section{EXPERIMENTAL AND RESULTS}

Preliminary experiments in which the urine from rats that had been injected with L-tyrosine $O\left[{ }^{35} \mathrm{~S}\right]$ sulphate $(1.5 \mathrm{mg} . / 200 \mathrm{~g}$. body wt.) was subjected to paper chromatography showed that the mobility of the unknown metabolite $\left(R_{F} 0 \cdot 28\right.$, see Dodgson et al. 1961) corresponded to that of the authentic sample of $p$-hydroxyphenylpyruvic acid $\left[{ }^{35} \mathrm{~S}\right]$ sulphate when the latter was chromatographed in the presence of normal rat urine. A similar agreement was obtained between electrophoretic mobility of metabolite and authentic sample. Both compounds could be detected on paper under ultraviolet light. These results could not consistently be repeated, however, and during these experiments, and others designed for the isolation of the metabolite, it became obvious that the material was subject to spontaneous changes similar to those undergone by the authentic sample of $p$ hydroxyphenylpyruvic acid $\left[{ }^{35} \mathrm{~S}\right]$ sulphate, which at room temperature is converted into $p$-hydroxybenzaldehyde $\left[{ }^{35} \mathrm{~S}\right]$ sulphate and $p$-hydroxyphenylacetic acid [ ${ }^{35}$ S $]$ sulphate (Rose \& Powell, 1963). In all subsequent experiments precautions were taken to collect urine immediately it was voided, and, as far as possible during subsequent manipulation, urine samples were kept at $2^{\circ}$ and extremes of $\mathrm{pH}$ were avoided.

\section{Keto-enol difference spectrum of the metabolite}

Rose \& Powell (1963) have shown that $p$-hydroxyphenylpyruvic acid $\left[{ }^{35} \mathrm{~S}\right]$ sulphate gives a characteristic keto-enol difference spectrum analogous to that given by free $p$-hydroxyphenylpyruvic acid

Bioch. 1963, 87 
(see Lin, Pitt, Civen \& Knox, 1958). A similar spectrum was obtained with the urine of rats that had been injected with L-tyrosine $O\left[{ }^{35} \mathrm{~S}\right]$-sulphate. A portion $(0.3 \mathrm{ml}$.) of the urine was washed through a column $(3.5 \mathrm{~cm} . \times 1 \mathrm{~cm}$.) of Dowex 50 ionexchange resin (200-400 mesh; $\mathrm{H}^{+}$form) with water and the acidic eluate was collected at $2^{\circ}$. $p$-Hydroxyphenylacetic acid $\left[{ }^{35} \mathrm{~S}\right]$ sulphate and the unknown metabolite were present in this fraction. A portion $(60 \mu \mathrm{l}$.) of the eluate was mixed with $200 \mu \mathrm{l}$. of $2 \mathrm{M}$-sodium arsenate containing $1 \mathrm{M}$-boric acid, the whole being adjusted to $\mathrm{pH} 6.4$ with conc. hydrochloric acid (test solution); a further $60 \mu \mathrm{l}$. portion was mixed with $200 \mu \mathrm{l}$. of $2.0 \mathrm{M}$-sodium arsenate adjusted to $\mathrm{pH} 6.4$ (control). After $15 \mathrm{~min}$. at room temp. the ultraviolet-absorption spectrum of the test solution was determined in $1 \mathrm{~cm}$. microcells (Hilger Uvispek), the control solution being placed in the blank cell. For comparison, potassium $p$-hydroxyphenylpyruvic acid ${ }^{[35}$ S] sulphate was added to normal rat urine $(400 \mu \mathrm{g} . / \mathrm{ml}$.), which was then treated exactly as described above except that $200 \mu l$. of the acid eluate from the ion-exchange column was mixed with $2.7 \mathrm{ml}$. of the borate or borate-arsenate solutions, spectrophotometric readings being made in normal $1 \mathrm{~cm}$. cells. In both cases a characteristic keto-enol difference spectrum was obtained $\left(\lambda_{\text {max. }} 302 \mathrm{~m} \mu\right)$. Normal rat urine gave no detectable keto-enol difference spectrum when treated in an identical manner.

A partially purified preparation of the metabolite was obtained as follows. Three rats received injections of L-tyrosine $O\left[{ }^{35} \mathrm{~S}\right]$-sulphate and the freeze-dried urine was dissolved in $1.5 \mathrm{ml}$. of water, before passing it through a column $(16 \mathrm{~cm} . x$ $1.7 \mathrm{~cm}$.) of Dowex 50 resin as described above. The fractions corresponding to the first peak of radioactivity were collected at $2^{\circ}$ as described by Dodgson et al. (1961), and, after they were pooled (total vol. approx. $2 \mathrm{ml}$.), the $\mathrm{pH}$ was adjusted to $7 \cdot 0$ with $5 \%$ potassium hydroxide solution. A portion $(250 \mu \mathrm{l}$.) of the solution was chromatographed as five spots and the radioactive metabolite was located on the wet paper. The appropriate areas of the wet paper were cut out, pooled and extracted with $0.75 \mathrm{ml}$. of ice-cold water. Control areas of identical dimensions were similarly extracted. The keto-enol difference spectrum of $60 \mu \mathrm{l}$. of each extract was then determined. Only the extract containing the metabolite gave a characteristic keto-enol difference spectrum.

\section{Conversion of metabolite into p-hydroxybenzaldehyde $\left.{ }^{35} \mathrm{~S}\right]$ sulphate}

Urine (1.5 ml.) from rats receiving L-tyrosine $O\left[{ }^{35} \mathrm{~S}\right]$-sulphate was treated as described in the preceeding section, the first radioactive eluate from the Dowex column being neutralized as before. This eluate was divided into two $0.7 \mathrm{ml}$. portions (solutions A and B). Solution A was kept at $-20^{\circ}$ and solution $B$ was adjusted to approx. $\mathrm{pH} 11$ (Universal indicator paper; British Drug Houses Ltd.) with $5 \%$ potassium hydroxide and kept at room temperature. Water was added appropriately to $\mathbf{A}$ to compensate for the small volume change involved in the adjustment of $\mathrm{pH}$. The disappearance of the metabolite from solution $B$ was then followed by measuring the keto-enol difference spectrum (10 $\mu \mathrm{l}$. of sample, $50 \mu \mathrm{l}$. of water and $200 \mu \mathrm{l}$. of borate-arsenate or arsenate buffer) at time-intervals of 1,4 and $24 \mathrm{hr}$. The keto-onol difference spectrum of solution $A$ was taken as representing the amount of metabolite present at zero time. The metabolite rapidly disappeared at $\mathrm{pH} 11.0$ (approx. $80 \%$ in $24 \mathrm{hr}$.). The keto-enol difference spectrum of solution $\mathbf{A}$ was checked after $36 \mathrm{hr}$. and was virtually unchanged. At the end of the experiment portions $(20 \mu \mathrm{l}$.) of each solution were mixed with $300 \mu$ l. of $0.1 \mathrm{~N}$ sodium hydroxide and the ultraviolet-absorption spectrum of $B$ was measured, $A$ being used in the blank cell. Solution B contained material having the characteristic absorption maximum of $p$ hydroxybenzaldehyde sulphate $\left(\lambda_{\max }, 256 \mathrm{~m} \mu\right.$, $\epsilon 15200$ in $0.1 \mathrm{~N}$-sodium hydroxide).

Subsequently, solutions A and B were subjected to paper chromatography together with a portion of the original urine that had been freeze-dried immediately after collection. The potassium salts of the $\left.{ }^{35} \mathrm{~S}\right]$ sulphate esters of $p$-hydroxyphenylpyruvic acid, $p$-hydroxyphenylacetic acid and $p$ hydroxybenzaldehyde were used as markers. Chromatograms of the freeze-dried urine showed the presence of small amounts of $p$-hydroxyphenylacetic acid [ ${ }^{35}$ S ] sulphate $\left(R_{F} \quad 0.5\right)$ and larger amounts of the metabolite. Solution $A$ gave sub. stantially the same pattern except for the presence of a faint spot corresponding in mobility to $p$ hydroxybenzaldehyde [ ${ }^{35} \mathrm{~S}$ ] sulphate $\left(R_{F} 0.57\right)$. The metabolite was barely detectable in the chromatographic pattern of $B$ but the spots corresponding to the $p$-hydroxyphenylacetic acid and $p$-hydroxybenzaldehyde derivatives were greatly intensified. Paper electrophoresis gave analogous results.

These findings provided further confirmation that the metabolite could undergo spontaneous conversion into $p$-hydroxybenzaldehyde [ $\left.{ }^{85} \mathrm{~S}\right]$ sulphate and also indicated a conversion into $p$ hydroxyphenylacetic acid $\left[{ }^{35} \mathrm{~S}\right]$ sulphate. The additional amounts of the latter compound in solution $B$ would not be reflected in the ultravioletabsorption spectrum of the solution, since the molecular extinction coefficient of the ester is very low $\left(\lambda_{\max } .265 \mathrm{~m} \mu, \epsilon 153\right.$; see Dodgson et al. 1961). 


\section{Conversion of metabolite into p-hydroxyphenylacetic acid $\left[{ }^{35} \mathrm{~S}\right]$ sulphate}

The spontaneous conversion of potassium $p$ hydroxyphenylpyruvic acid $\left[{ }^{35} \mathrm{~S}\right]$ sulphate into the corresponding $p$-hydroxyphenylacetic acid derivative (Rose \& Powell, 1963) did not proceed readily in aqueous solution but occurred when paper chromatograms of the pyruvate derivative were exposed to the atmosphere. The metabolite underwent a similar conversion not only on paper chromatograms but also in urine. The urine of six rats that had been injected with L-tyrosine $O\left[{ }^{35} \mathrm{~S}\right]$. sulphate was divided into two equal parts (urines 1 and 2). Urine 1 was kept at $-20^{\circ}$ for 3 days; urine 2 was adjusted to approx. $\mathrm{pH} 7$ (Universal indicator paper) with $5 \%$ potassium hydroxide and kept at room temperature for the same period. Subsequently, samples of both urines were passed through Dowex resin and the first radioactive peak was collected at $2^{\circ}$ as described above. The ketoenol difference spectrum of a sample of each eluate showed that over $90 \%$ of the metabolite had disappeared from urine 2. The eluates were then chromatographed together with samples of the original urines 1 and 2 (i.e. before Dowex treatment). The appropriate marker compounds were run on the same paper. The eluate from urine 1 gave two radioactive spots corresponding to $p$ hydroxyphenylpyruvic acid $\left[{ }^{35} \mathrm{~S}\right]$ sulphate and $p$ hydroxyphenylacetic acid $\left[{ }^{35} \mathrm{~S}\right]$ sulphate respectively, the eluate from urine 2 showed the latter compound only, the spot being greatly intensified. Similar results were obtained with the urines 1 and 2 before passage through Dowex resin except that in each a trace of L-tyrosine $O\left[{ }^{35} \mathrm{~S}\right]$-sulphate was also present. Paper electrophoresis gave analogous results.

Authentic $p$-hydroxyphenylpyruvic acid $\left[{ }^{35} \mathrm{~S}\right]$ sulphate was also converted into $p$-hydroxyphenylacetic acid $\left.{ }^{35} \mathrm{~S}\right]$ sulphate when added to normal rat urine and kept for 3 days at room temperature. No such change could be detected in pure aqueous or buffered solutions over the same period of time.

\section{DISCUSSION}

This work, together with that of Dodgson et al. (1961), shows that L-tyrosine $O\left[{ }^{35} \mathrm{~S}\right]$-sulphate is metabolized by the rat to yield $p$-hydroxyphenylpyruvic acid [ $\left.{ }^{35} \mathrm{~S}\right] \mathrm{sulphate}$ and $p$-hydroxyphenylacetic acid $\left[{ }^{35} \mathrm{~S}\right]$ sulphate. This finding is in accord with theoretical considerations since it is clear that the normal metabolic pathway whereby $\mathrm{L}$-tyrosine is degraded could not be followed, beyond its first stage, by the corresponding sulphate ester. This normal metabolic pathway involves deamination to yield $p$-hydroxyphenylpyruvic acid followed by ring hydroxylation and molecular rearrangement to give homogentisic acid. Such a rearrangement could not take place if the phenolic hydroxyl group of $p$-hydroxyphenylpyruvic acid was esterified with sulphuric acid. Under these circumstances it would be expected that $p$-hydroxyphenylpyruvic acid sulphate would accumulate and undergo conversion into the corresponding $p$ hydroxyphenylacetic acid derivative. Analogous transformations have been shown to occur with free L-tyrosine (Booth et al. 1960) although the route is a relatively minor one. Dodgson et al. (1961) assumed that the conversion of the $p$ hydroxyphenylpyruvic acid $\left[{ }^{35} \mathrm{~S}\right]$ sulphate into the $p$-hydroxyphenylacetic acid ester would involve an enzymically controlled aerobic decarboxylation. This view should be re-appraised in the light of the relative ease with which the conversion appears to occur spontaneously in urine under mild experimental conditions. The nature of the catalytic factor(s) that facilitate this conversion in urine is not known.

Other work, with guinea pigs and mice, in these Laboratories has shown that the fate of L-tyrosine $O\left[{ }^{35} \mathrm{~S}\right]$-sulphate in these animals is similar to that in rats, although some quantitative differences are apparent (T. Flanagan, unpublished work). Collectively, the results presumably explain why Grimes (1959) failed to detect L-tyrosine $O$-sulphate in the urine of these animals although the presence of the ester as a product of fibrinogen metabolism would be forecast on theoretical grounds. At the same time, the results point to the anomalous position of the human organism where L-tyrosine $O$-sulphate is present in urine in relatively large amounts (up to $30 \mathrm{mg}$./day; Tallan, Bella, Stein \& Moore, 1955). This fact would imply that the human does not possess the necessary enzyme system for the deamination of L-tyrosine $O$-sulphate. Alternatively, if such a human enzyme does exist, the implication is that the observed $L$ tyrosine $O$-sulphate content of human urine represents only a portion of the total amount of the ester that is disposed of each day. If this were so, then, in the light of the reasoning (see Dodgson, 1958) that urinary L-tyrosine $O$-sulphate originates from protein-bound residues, it would suggest that such residues are not exclusive to fibrinogen.

\section{SUMMARY}

1. It has been shown that the unknown sulphate ester excreted when L-tyrosine $O\left[{ }^{35} \mathrm{~S}\right]$-sulphate is injected into rats (Dodgson et al. 1961) is the [ $\left.{ }^{35} \mathrm{~S}\right]$ sulphate ester of $p$-hydroxyphenylpyruvic acid.

2. This compound is unstable and readily undergoes spontaneous conversion into $p$-hydroxybenzaldehyde $\left[{ }^{35} \mathrm{~S}\right]$ sulphate at room temperatureand 
alkaline $\mathrm{pH}$ and into $p$-hydroxyphenylacetic acid $\left[{ }^{35} \mathrm{~S}\right]$ sulphate in the presence of urine at neutral $\mathrm{pH}$.

3. The implications of these various findings are discussed.

We are grateful to the Medical Research Council and to The Royal Society for financial support.

\section{REFERENCES}

Booth, A. N., Masri, M. S., Robbins, D. J., Emerson, O. H., Jones, F. T. \& DeEds, F. (1960). J. biol. Chem. 235, 2649.
Dodgson, K. S. (1958). Proc. 4th int. Congr. Biochem., Vienna, 13, Colloq. (a), 23.

Dodgson, K. S., Powell, G. M., Rose, F. A. \& Tudball, N. (1961). Biochem. J. 79, 209.

Grimes, A. J. (1959). Biochem. J. 73, 723.

Lin, E. C. C., Pitt, B. M., Civen, M. \& Knox, W. E. (1958). J. biol. Chem. 233, 668.

Powell, G. M., Rose, F. A. \& Dodgson, K. S. (1962). Biochem. Biophys. Res. Commun. 7, 23.

Rose, F. A. \& Powell, G. M. (1963). Biochem. J. 87, 541.

Tallan, H. H., Bella, S. T., Stein, W. H. \& Moore, S. (1955). J. biol. Chem. 217, 703.

Biochem. J. (1963) 87, 548

\title{
Studies on L-Tyrosine $\boldsymbol{O}$-Sulphate
}

\section{THE METABOLIC FATE OF THE L-TYROSINE $O\left[{ }^{35}\right.$ S]-SULPHATE RESIDUE OF ${ }^{35}$ S-LABELLED RABBIT FIBRINOPEPTIDE B}

\author{
By J. G. JONES, K. S. DODGSON, GILLIAN M. POWELL AND F. A. ROSE \\ Department of Biochemistry, University College, St Andrew's Place, Cardiff
}

(Received 11 December 1962)

L-Tyrosine $O$-sulphate is known to be a component of mammalian fibrinogens (Bettelheim, 1954; Blombäck, 1960). In the ox, pig and rabbit the ester occurs in one of the two peptides (fibrino. peptide B) that are liberated from fibrinogen by the action of bovine thrombin. In man, however, although L-tyrosine $O$-sulphate is present in fibrinogen (Bettelheim-Jevons, 1958), there is some evidence to suggest that it is not present in fibrinopeptide B (Korff \& Bronfenbrenner, 1958; Blombäck, Blombäck, Edman \& Hessel, 1962).

Attempts made in these and other Laboratories (e.g. Segal \& Mologne, 1959; Grimes, 1959; Vestermark \& Boström, 1959) to achieve the enzymic sulphation of free L-tyrosine in vitro by the normal adenosine $3^{\prime}$-phosphate $5^{\prime}$-sulphatophosphate-phenol-sulphokinase route have all failed, and there is some evidence to suggest that the amino acid must be present in a peptide-bound form before sulphation can occur. This lends support to the possibility that the relatively large amounts of L-tyrosine $O$-sulphate that are found in normal human urine (up to $30 \mathrm{mg}$./day; Tallan, Bella, Stein \& Moore, 1955) arise from the degradation of protein, presumably fibrinogen. In contrast with humans, rats, mice and guinea pigs do not appear to excrete L-tyrosine $O$-sulphate in urine (Grimes 1959), but this is not surprising in view of the ability of these species to deaminate the ester to yield the sulphate esters of $p$-hydroxyphenylpyruvic acid and $p$-hydroxyphenylacetic acid (Dodgson, Powell, Rose \& Tudball, 1961; Powell,
Rose \& Dodgson, 1962, 1963). In an attempt to throw further light on the metabolism of $\mathrm{x}$-tyrosine $O$-sulphate residues when present in peptide-bound form, a study has been made of the metabolic fate, in rabbits, of free L-tyrosine $O\left[{ }^{35} \mathrm{~S}\right]$-sulphate and of rabbit fibrinopeptide $B$ in which the L-tyrosine $O$-sulphate residue is labelled with ${ }^{35} \mathrm{~S}$.

\section{MATERIALS AND METHODS}

Sulphate esters. The ${ }^{35}$ S-labelled sulphate esters of Ltyrosine and $p$-hydroxyphenylacetic acid were prepared as described by Dodgson et al. (1961).

${ }^{35}$ S-labelled rabbit fibrinopeptide $B$. Eight virgin female rabbits (Flemish Giants, each weighing approx. $3 \mathrm{~kg}$.) were each injected intraperitoneally with a total of $6 \mathrm{mc}$ of $\mathrm{Na}_{2}{ }^{85} \mathrm{SO}_{4}$ (code SJS 1, specific activity greater than $100 \mathrm{mc}$ / mg. of S; The Radiochemical Centre, Amersham, Bucks.) over a period of 3 days. Sixteen hours after the last injection the animals were anaesthetized with ether and the blood was drawn from the abdominal aorta and collected in vessels containing a $4 \%$ solution of sodium citrate. The volume of sodium citrate solution used was such that the final concentration of citrate in the blood sample was approx. $0.4 \%$.

Red cells were separated by centrifuging at $2000 \mathrm{~g}$ and $10^{\circ}$ for $1 \mathrm{hr}$. and the ${ }^{35} \mathrm{~S}$-labelled fibrinogen was isolated from the plasma by method 6 of Cohn et al. (1946). Subsequently, the fibrinogen was purified by the glycine method of Blombäck \& Blombäck (1956) as far as stage I-o (yield approx. $7 \cdot 5 \mathrm{~g}$. wet wt.). The fibrinogen was then clotted with bovine thrombin and fibrinopeptide $B$ separated by fractionation of the clot supernatant on Dowex 50 according to the procedures outlined by Blombäck, 